\title{
A new evaluation index system of the assessment of higher education in China
}

\author{
CAO Lijuan ${ }^{1}$ LI Meng $^{2}$ \\ ${ }^{1}$ Department of accounting Luoyang Institute of Science and Technology Luoyang, China \\ ${ }^{2}$ Office of Academic Affairs Luoyang Institute of Science and Technology Luoyang, China
}

\begin{abstract}
-
A new education index system is required in order to comprehensively improve the quality of higher education and achieve the training goal of applied talents. The education index system should be established by choosing the appropriate assessment methods. These methods could be selected by contrasting their advantages and disadvantages and analyzing the characteristics of various modules and teaching links. The evaluation index system can be effectively used to assess applied talents comprehensively and systematically. Establishing the evaluation index system is good for achieving the training goal, improving the quality of education and teaching, and enhancing the overall quality of students.
\end{abstract}

Keywords: Student Assessment; Training program; Newly-built Universities and College;

\section{Introduction}

At present, in China, the main aim of HE is to cultivate students for two possible routes: study for academic research or for practical application, but the existing evaluation system is of little benefit for the current personnel training objectives. In China, the existing evaluation system has two drawbacks: On the one hand, the traditional assessment methods attach too much importance to screening and selection, those methods are always used for evaluating students' learning and skills, so comprehensive study of the process of student learning and personality development are neglected and what is more, the cultivation of students' innovative spirit and practical ability have been affected. On the other hand, because the traditional assessment methods are used, students are only passively involved in the assessment and they lack motivation to participate in assessment. So, in order to meet the training objectives of HE in China, a new evaluation index system with different kinds of assessment methods and weights should be established.
2. Description of several exams of various sorts and specific assessment formats

China's HE is usually recognized nationally as a "brand" with a discernible worth attached to it. China's HE is looking for a balance between academic and practical application, but most colleges or universities do not have clear development goals, at least none which are reflected in terms of student evaluation ${ }^{[2-3]}$. After they gain their degrees and leave campus, students are widely considered to be highly talents, not only for work, but also for research. But the actual situation is so far from the general public imagination, after graduate, the working capabilities of many students might be improved by work environments, even worse; some students cannot find jobs. In recent years, China's HE has changed with many colleges and universities finding their clear development goals. Furthermore, HE in China is growing and improving rapidly so this situation calls for new assessment methods. Different goals of colleges and universities need to establish different student evaluation index systems. Applied colleges and universities should pay more attention to the assessment of the students' quality of skills, ability to apply their knowledge and practical ability. Students' learning would be typically assessed by essays and examinations. Contemporary and future methods of learning, teaching and assessment need to go way beyond this if they are to fulfill the complex needs of society ${ }^{[4]}$. 


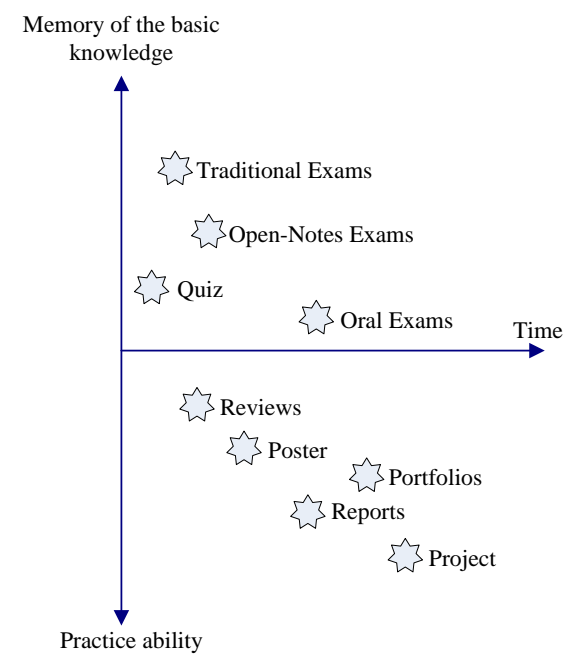

Fig. 1Validity of assessment methods

As a result of the impact of domestic economy, politics, culture, and foreign educational philosophy, HE institutions in China have developed strategies on teaching and learning. Therefore, advanced assessment methods should be introduced and then a new evaluation index system should be established. In recent years, in developed countries, advanced assessment methods can be divided into two categories: exams of various sorts and specific assessment formats. And each category has its own different methods. For example, the first category includes traditional exams, quiz, open-book, open-notes, and structured exams, as well as vivas(oral exams) and other kinds of examination, while the second category contains essays, reviews, reports, presentations, practical work, portfolios, student projects, poster displays, and so on[5]. It is easy to find that the first category pays more attention to tutors' attitude on teaching, and the second one is more student-centre. The authors have identified nine assessment methods which could be implemented in Chinese colleges and universities and which could be used to establish the new education index system. Table 1 illustrates advantages and disadvantages of those nine methods ${ }^{[5]}$.

Table. 1 Nine assessment methods

\begin{tabular}{|c|c|c|c|}
\hline Rank & method & Advantages & Disadvantages \\
\hline 1 & $\begin{array}{l}\text { Traditional } \\
\text { exams }\end{array}$ & $\begin{array}{c}\text { Relatively economical; } \\
\text { Equality of opportunity; } \\
\text { familiar with students and } \\
\text { tutors } \\
\end{array}$ & $\begin{array}{c}\text { Low validity; little or no } \\
\text { feedback; surface } \\
\text { learning }\end{array}$ \\
\hline 2 & $\begin{array}{l}\text { Open-notes } \\
\text { exams }\end{array}$ & $\begin{array}{c}\text { Significant learning; } \\
\text { Reduce memory; tested } \\
\text { more effectively }\end{array}$ & $\begin{array}{l}\text { Need rehearsal; addicted } \\
\text { to Open-notes exams }\end{array}$ \\
\hline 3 & Quiz & $\begin{array}{c}\text { Timely feedback; Short } \\
\text { time cost; Convenience of } \\
\text { the organization }\end{array}$ & $\begin{array}{c}\text { Can not be used for } \\
\text { assessing systematic } \\
\text { knowledge of and ability } \\
\text { of problems resolving }\end{array}$ \\
\hline 4 & Oral exams & $\begin{array}{l}\text { Authenticity is tested } \\
\text { directly and indeed } \\
\text { quickly; Useful when } \\
\text { searching for particular } \\
\text { things; fairly ;useful } \\
\text { practice for interviews of }\end{array}$ & $\begin{array}{c}\text { Agenda may leak'; } \\
\text { Standards of results is } \\
\text { not objective; someone } \\
\text { can not show themselves } \\
\text { well }\end{array}$ \\
\hline
\end{tabular}

\begin{tabular}{|c|c|c|c|}
\hline \multicolumn{4}{|c|}{ employment } \\
\hline 5 & Portfolios & $\begin{array}{c}\text { Validity can be high; } \\
\text { timely feedback } \\
\text { Reflect development; } \\
\text { Easy for authenticity } \\
\text { assessments; Record } \\
\text { students attitudes and } \\
\text { values for skills and } \\
\text { knowledge. }\end{array}$ & $\begin{array}{c}\text { Too much information } \\
\text { to assess for employers; } \\
\text { evaluation is too } \\
\text { subjective }\end{array}$ \\
\hline 6 & Reports & $\begin{array}{l}\text { Relevant to many careers } \\
\text { and professional areas; } \\
\text { The end product which } \\
\text { reflects students' } \\
\text { comprehensive capacity. } \\
\text { More personality }\end{array}$ & $\begin{array}{c}\text { Students and tutors } \\
\text { spend a lot of time; } \\
\text { Collaboration is difficult } \\
\text { to detect; }\end{array}$ \\
\hline 7 & $\begin{array}{l}\text { Students } \\
\text { projects }\end{array}$ & $\begin{array}{c}\text { developing innovative } \\
\text { ability.; Practice } \\
\text { comprehensive ability }\end{array}$ & $\begin{array}{c}\text { Difficult to choose } \\
\text { criterion of } \\
\text { assessment; .Assessment } \\
\text { s lag }\end{array}$ \\
\hline 8 & Reviews & $\begin{array}{c}\text { High validity; Active } \\
\text { process; Involves } \\
\text { cognitions processes; } \\
\text { Practice for research } \\
\text { writing }\end{array}$ & $\begin{array}{l}\text { Lack practice of co- } \\
\text { operation; Different } \\
\text { sources may make } \\
\text { harder to assess }\end{array}$ \\
\hline 9 & $\begin{array}{c}\text { Poster } \\
\text { displays and } \\
\text { exhibitions }\end{array}$ & $\begin{array}{c}\text { Peer-assessment; Timely } \\
\text { feedback }\end{array}$ & $\begin{array}{c}\text { The results of } \\
\text { assessment may be more } \\
\text { subjective; The } \\
\text { evaluation results are } \\
\text { difficult to grade } \\
\text { students }\end{array}$ \\
\hline
\end{tabular}

Every method will be time-consuming for students and tutors. Different method costs different time, for example, making a project may require a much longer time than other assessment methods. Exams of various sorts emphasize memory of the basic knowledge, and specific assessment formats pay more attention to students' practice ability. Furthermore, each method has difference with each other; the figure 1 shows details about validity of those methods.

\section{An evaluation index system for higher education assessment}

It is well known that the quality of $\mathrm{HE}$ is directly reflected by the student's knowledge structure, practical ability and personal qualities. The training goal of new undergraduate colleges is to bring up applied talents [6]. The students' knowledge structure, professionalism and personal qualities should meet the specific job and career, in the same way that factories produce products which meet the specific needs of people. However, due to the single-sided assessment method, too much emphasis on results and grading, and unable to effectively examine the process of personnel training, therefore, an innovative evaluation index system is imperative. The establishment of the new evaluation index system is designed by using advanced assessment methods, combining assessment methods creatively, giving corresponding weights through which different kinds of modules could be evaluated. Through the innovative combination of assessment methods, the purpose of the index system is to evaluate the level to which students master the basics of knowledge, practical ability, and personal qualities. By using the evaluation index system, not only will students develop, but also tutors will be able to 
identify problems in a timely manner and give guidance for students.

\subsection{Principles of building the evaluation index system}

Establishment of the evaluation index system should be able to follow some principles:

- As the basis of achieving the training goal, the positioning of the student evaluation index system should comply with principles of "develop goaloriented".

- The evaluation indicators should be picked up by paying attention to the structure of students' knowledge, professional abilities and personal qualities, such as portfolio, students project, oral exams, and so on.

- The evaluation criteria of indicators which are largely affected by human factors could be refined during the comprehensive evaluation stage.

- To guarantee the reliability and validity of the results of the evaluation, the evaluation indicators should be chosen to reflect the impartiality and objectivity.

\subsection{The establishment of evaluation index system framework}

According to the current Chinese applied undergraduate colleges and universities curriculum structure, the evaluation index system is constructed based on the basic content of basic curriculum for one class index, curriculum evaluation methods for secondary index, and weight set reference. The details of the index system framework are shown in Table II.

Table. 2 The Education index system

\begin{tabular}{|c|c|c|}
\hline rst level indicators & $\begin{array}{c}\text { Second level } \\
\text { indicators }\end{array}$ & Weight (\%) \\
\hline \multirow{3}{*}{ Public Basic Modules } & Traditional Exams & $60-70$ \\
\hline & Quiz & \\
\hline & Poster Displays* & \\
\hline \multirow{3}{*}{$\begin{array}{c}\text { Professional Basic } \\
\text { Modules }\end{array}$} & Open-notes Exams & $40-50$ \\
\hline & Quiz/Oral Exams ${ }^{\Delta}$ & \\
\hline & Portfolios & \\
\hline \multirow{3}{*}{$\begin{array}{c}\text { Professional } \\
\text { Modules(Compulsory } \\
\text { modules/Optional) }\end{array}$} & $\begin{array}{c}\text { Report / Students } \\
\text { Project }^{*}\end{array}$ & $40-50$ \\
\hline & Portfolios & \\
\hline & Quiz/Reviews ${ }^{\Delta}$ & \\
\hline Public Elective Modules & Portfolios & 100 \\
\hline \multirow[t]{2}{*}{ Curriculum Design } & $\begin{array}{c}\text { Report /Students } \\
\text { Project* }^{*}\end{array}$ & $60-70$ \\
\hline & Oral Exams ${ }^{\Delta}$ & \\
\hline \multirow{2}{*}{ Specialized Practice } & Reports $^{\Delta}$ & $50-60$ \\
\hline & Portfolios & \\
\hline \multirow{2}{*}{ Graduation Practice } & Reports $^{\star}$ & $50-60$ \\
\hline & Portfolios $^{\star}$ & \\
\hline \multirow{3}{*}{ Graduation Design } & Reports & $50-60$ \\
\hline & Oral exams ${ }^{\Delta}$ & \\
\hline & Portfolios & \\
\hline
\end{tabular}

\subsection{The interpretations of the evaluation index system}

(1)Explanations for one class indicators

One class index is the current applied undergraduate colleges and universities each professional course category, mainly divided into two categories: First, theoretical modules, including public basic modules, professional basic modules, professional modules (obligatory/electives), and public elective modules; Second, practice link, including curriculum design, specialized practice, graduation practice and graduation design. The first course category pays attention to basic theoretical knowledge learning and reserve, and personality development needs. The second course category attaches great importance to the practice and professional knowledge which are used in work; the courses reflect the students' professional skills, professional quality and ability of work.

(2)Explanations for secondary indicators

Secondary indicator selection is advanced assessment methods, and they are combined reasonably according to the characteristics of the course category. The traditional evaluation methods are mechanical and single, and they pay attention to the results and ignore the process to achieve the training goal. Such as: single adopts the traditional test methods could lead to a situation that students do not pay attention to study in daily life, but before the exam, they may use a very short period of time for preparing the final exam, even worse, this way of study will induce students hold the utility, speculative attitude towards learning and evaluation, which lead to the dislocation of the students' outlook on life and values. The selection of assessment methods and cooperation in this evaluation index system pay more attention to the learning process, and can guide students to active learning, critical study, the pursuit of personality development and innovation, in order to make students actively participate in the evaluation process. Setting up the secondary indicators reflects the diversity and differences of HE.

(3)Weight explanation

This evaluation index system not only highlights the creativity in the selection of assessment indicators, but also fully embodies the consistency of the target and training in the evaluation patterns and the choice of weight. Evaluation patterns adopts the participating design concept, different modules should use different patterns of evaluation, and provides more objective, more real and effective evaluation conclusions. For examples, poster displays can take students in leading the way, and the tutors adjust the weights of the results; In oral exams, peer tutors could be invited to evaluate; Results of graduation practice evaluation mainly reference the evaluation results which are given by employers. Different with the traditional way of weight, this index system of the weight is interval value, and only the main weighting, other indicators weights with important evaluation methods and the evaluation method is to use frequency and adjustment. The indicators' weights could be adjusted in different institutions. 


\section{Discussion and outlook}

Based on the deeply analysis of training goals in newly founded colleges and, a new evaluation index system which are compared with analysis of different assessment methods are established. This evaluation index system reflects three kinds of abilities, such as master of the basic knowledge, development of practice ability and improvement of innovative capability, through the different indicators combination. The weights of the secondary indicators could be adjusted according to the students' actual situation and the class feedback. At the end, a case is design to show how to use the evaluation index system and feedback process. The case illustrates that the evaluation index system is feasible and operable.

Student evaluation innovation is a pilot project, the weight of each secondary indicator directly impact assessment results and evaluation guide, so in the test process, further research should be discussed in applying secondary indicators and adjustment of weights.

\section{References}

[1] WANG Zhong jing, HU Qiang, CHEN Lin.(2009),"Research and design on applicationoriented education program of university ".Education and Teaching Research, Vol.23No.10,53 55

[2] CHAI Hong min, LI Xiu qin, LIU Zeng jin, ZHANG Wei wei.(2009),"Theoretical analysis on reformation of talent training pattern and training project".Journal of North China Institute of Water Conservancy and Hydroelectric Power, Vol.25No.3,102 104

[3] Ruth Helyer, (2011), "Aligning higher education with the world of work". Higher Education, Skills and Work-based Learning, Vol.

[4] Race, P. and Smith, B. 500 Tips on Assessment, 2nd Edition [M].London : Routledge, 2005, 26

[5] GU Yong an, XU Ting, LU Zheng li. New undergraduate colleges restructuring and development theory[M].Beijing : China Social Sciences Press, 2012, 184

[6] HUANG Guo hua, SUN Shu juan.(2009),"Value analysis of general education in cultivating undergraduate applied professionals_— Taking newly established university as a survey centre". Theory and Practice of Education, Vol.29,18-20 